\title{
AN UNPUBLISHED LETTER OF WILLIAM GILMORE SIMMS
}

\section{BY HERBERT SMITH}

Professor SMITH is a member of the Department of English at the University of Wisconsin.

I

$\mathrm{N}$ the Philhower Collection of the Rutgers University Library is a letter of William Gilmore Simms which is the only known letter bearing directly upon one of the least known areas of his post-war career-his brief Masonic affiliation. Simms apparently became a Freemason late in the year I 865 , probably introduced to the society by the husband of one of his wife's cousins, Christopher McKinney Rivers. ${ }^{1}$ His immediate reasons for joining are, of course, unknown and unknowable, but his activities in regard to the society suggest that he saw membership in it as a possible help to his straitened circumstances in the wrecked post-war South.

Indeed, Simms's affiliation with Freemasonry was a marriage of convenience from the very beginning. His first trip to the North after the war was financed by the South Carolina lodge. In November, 1865, he journeyed to New York, ostensibly "to interest the Masonic fraternity in behalf of their destitute brethren in [South Carolina ]."2 But, though the trip was paid for by Masonic contributions, Simms did not hide the fact that he had "business there of my own." Without the Masonic commission Simms would not have been able to finance a trip North for some time.

Except for the new evidence of the letter in the Philhower Collection, the evidence of Simms's Masonic affiliation would virtually come to an end at this point. There are few further references to the fraternity, and all of them seem to suggest rather a diminishing than an increasing interest in things Masonic. But the Philhower Collection letter, previously unpublished, proves that Simms used

${ }^{1}$ The Letters of William Gilmore Simms, Mary C. Simms Oliphant, Alfred Taylor Odell, T. C. Duncan Eaves, eds. (University of South Carolina Press, Columbia, S.C., I 955$), \mathrm{V}$, I 37-38.

2 Simms Letters, IV, 525 .

${ }^{3}$ Simms Letters, IV, 522, 524 . 
his Masonic connections in the North for at least one publication. ${ }^{4}$ Sixty years old, with over fifty volumes of fiction and verse behind him, Simms wrote very little after the Civil War. A few short stories published in periodicals were the limit of his output during these last years of his life. But in his impoverished situation, he had nothing to live by except his pen and his reputation-and the possibility of reprinting some of those many works his reputation was built upon. This letter illustrates how, through his Masonic connections, he managed at least one reprinting to the tune of two hundred dollars, no small matter for a man financially ruined through the fortunes of war.

\section{Dean Street, Brooklyn I 5 th Aug $^{\mathrm{t}}$, i 866}

My dear Mr. Ellis:

Have you received the photographs I sent you from Yonkers, \& do they satisfy you. The head and face are those of an ourson ${ }^{6}$ of the antique, and all that have ever been made of me are villainously like-yet unlike. My eyes being very sensitive to any light or strain upon them,-in consequence of my being sun-struck when young-at once contract themselves \& all the muscles about them, the moment the machine is brought to bear upon them. The engraver should be instructed to do some "Eye-opening" while working on the picture. Verily I am always shocked to see what a grisly bear I present to the world, with every picture made by the instrument. You might get a more amicable, \&, I think, quite as natural \& true a portrait, by adopting that which accompanies my poems, in Newfields' Edition. So again, you will find an excellent profile likeness, published in Griswold's International Magazine. These were made some 20 years ago, \& are thought to be very good presentments of the subject at that date. As respects my appearance, I am free to say, I am quite indifferent (which I ought not to be) but it is your policy to exhibit your bears, or lions, under the most favorable aspects.When will you commence your "Sunny Side Series." I think you do wisely

\footnotetext{
${ }^{4}$ The letter is valuable also in suggesting very strongly that Simms's letter No. I I 83 (Simms Letters, IV, 586-87), in the Simms Collection of the New York Public Library, is wrongly described in Simms Letters as addressed to Fletcher Harper. The editors assumed that references in the letter to "the Brethren" suggest the Harper brothers; in the light of the Philhower letter it seems far more likely that the NYPL fragment is also directed to Mr. Ellis and the Masonic "brethren" Simms encountered in Trenton.

${ }^{5}$ The address of William Hawkins Ferris, Simms' publisher in New York.

"Illegible in the Ms., but probably "ourson," French for "bear-cub," since the image is picked up later in the letter.

${ }^{7}$ Simms's volume in the series was entitled The Ghost of My Husband: A Tale of the
} 
in choosing that title. I shall be glad to see you beginning and shall rejoice to learn that you succeed. This will depend wholly upon the degree of dash, novelty, and general ability which you employ. It will be in my power, I modestly think, to prepare as soon as the Summer is over,--and I think of doing it-a series of novellettes, [sic] which shall be unique and freshdistinguished by passion [illegible] and, perhaps, fun \& frolic. ${ }^{8}$ You may think it strange, but my penchant for humor, fun \& gaiety, is always more active when my sadness is most pressing; so that, I tell my friends, if you find my letters lively, you may conclude that I am at my saddest. But this is sorry egotism.

I think, my dear Mr. Ellis, that you and Mr. Chapman are both perfectly aware of the importance, to me, of realizing, from my poor brain all the pecuniary results possible, and that you will take care to let me have my quid,-in part, at least-before I depart for the South. Will you be so good as to say in what manner this shall be done? You were to pay me $\$ 100$ by the 20th Augt. and the remaining $\$ 100$ by the 20th Sept. How, $\&$ on whom, shall I draw? Advise me, if you please, of all necessary particulars.

I shall be pleased, if possible, to visit Trenton, and as it is not unlikely that I shall return South by the land route, I may have a chance to look in upon you \& our brethren of the Mystic tre ${ }^{9}$ when you least expect it. Present me gratefully to yr. medico (Dr. C.), our medical brother. I may need a potion at his hands. Commend me to him expressly, to the fraternity generally, and hold me as ever

very truly yours,

W. Gilmore Simms.

P.S. Brady, by the way, has taken several portraits (photographs) of me for a large quarto work of the publisher, Johnson. ${ }^{10} \mathrm{He}$ has also made some cartes de visite-all frightful-more so than those I sent you, since they were taken when I wore all my fearful wilderness of beard. But it may be well to look in at Brady's \& see them.

W.G.S.

Crescent City (New York, Chapman and Company, c.I 866). It was number two of the "Sunny Side Series." 'The novelette was originally published in a collection under its original title, Marie de Berniere, by Lippincott in 1853 .

${ }^{8}$ This series, of course, never came about. The Ghost of My Husband was the only title by Simms in the series. Simms died in 1870 , and his production of fiction during his last years was limited to a very few short stories.

${ }^{9}$ Illegible in the Ms., but apparently a Masonic symbol of some kind, from the context meaning something like "assembly" or "company." I have submitted the symbol to several Freemasons, but no one has been able to identify it.

${ }^{10}$ See Simms Letters, IV, 606. 